\title{
Turkish Society of Cardiovascular Surgery (TSCVS) Proposal for use of ECMO in respiratory and circulatory failure in COVID-19 pandemic era
}

\author{
COVID-19 pandemi çağında solunum ve dolaşım yetmezliğinde ECMO kullanımına ilişkin \\ Türk Kalp ve Damar Cerrahisi Derneği (TKDCD) önerileri
}

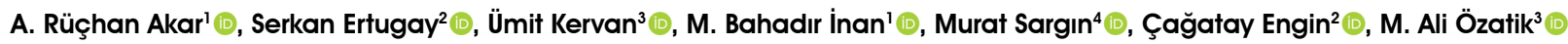 \\ Institution where the research was done: \\ Multicenter \\ Author Affiliations: \\ 'Department of Cardiovascular Surgery, Ankara University School of Medicine, Ankara, Turkey \\ 2Department of Cardiovascular Surgery, Ege University School of Medicine, Izmir, Turkey \\ ${ }^{3}$ Department of Cardiovascular Surgery, Ankara City Hospital, Ankara, Turkey \\ ${ }^{4}$ Department of Cardiovascular Surgery, Siyami Ersek Thoracic and Cardiovascular Surgery Training and Research Hospital, Istanbul, Turkey
}

\begin{abstract}
The document is prepared to guide the members of the The Turkish Society of Cardiovascular Surgery (TSCVS) and other extracorporeal membrane oxygenation (ECMO) centers worldwide to share experiences in using ECMO in COVID-19 pandemic.
\end{abstract}

Keywords: Extracorporeal membrane oxygenation, pandemics, respiratory distress syndrome, shock.

\section{THE MAJOR CLINICAL PROBLEM}

Coronavirus disease 2019 (COVID-19) is an explosive viral pandemic of zoonotic origin. The disease is threatening the entire world and is potentially fatal..$^{[1]}$ Using the electron microscopic images, description of the structure, and genomic features of the new virus, it was named as novel severe acute respiratory syndrome (SARS)-CoV-2. Novel SARS-CoV-2 virus is highly transmissible through person-to-person contact with respiratory droplets. It is well defined that an essential feature of a new virus is the capacitance of being highly infectious (R0: 2.2). ${ }^{[2,3]}$ Transmission may occur from both symptomatic and asymptomatic patients. ${ }^{[4]}$ Viral human cell invasion is maintained
$\ddot{O} Z$

Bu doküman Türk Kalp ve Damar Cerrahisi Derneği (TKDCD) dernek üyelerine ve tüm dünyadaki diğer ekstrakorporeal membran oksijenasyon (ECMO) merkezlerine rehberlik etmesi ve COVID-19 pandemisinde ECMO kullanımına ilişkin deneyimleri paylaşmak amacıyla hazırlanmıştır.

Anahtar sözcükler: Ekstrakorporeal membran oksijenasyonu, pandemi, solunum zorluğu sendromu, şok.

by the angiotensin-converting enzyme-2 (ACE-2) receptor.Among hospitalized cases, the severe disease was reported in $15 \%$ of the cases, and fatality occurred in $12 \%$ of these cases, with higher case-fatality rates in older adults. ${ }^{[5]}$

The Chinese health authorities reported the first cluster of cases $(n=41)$ with COVID-19 to the World Health Organization (WHO) on the date of December 31, 2019. Epidemiological studies have suggested the exposure to Huanan Seafood Wholesale Market in this cluster, and the market was closed on January 1, 2020. Phylogenetic analysis of the complete viral genome of the single patient who was a worker at the market revealed that the virus was most closely related

Received: March 19, 2020 Accepted: March 29, 2020 Published online: March 30, 2020

Correspondence: A. Rüçhan Akar, MD. Ankara Üniversitesi Tıp Fakültesi Kalp ve Damar Cerrahisi Anabilim Dalı, 06590 Çankaya, Ankara, Türkiye. Tel: +90 312 - 5956800 e-mail: akarruchan@gmail.com 
(89.1\% nucleotide similarity) to a group of SARS-like coronaviruses. ${ }^{[6]}$ Later on, it was shown that the new type of coronavirus originated in bats and was transmitted to humans through unknown intermediary animals in Wuhan, Hubei province of China. ${ }^{[7]}$ As a result of global spread, the outbreak has been labeled as a pandemic by the WHO on March 11, 2020.

As of March 25, 416,916 cases were reported in Europe with a rate of $30 \%$ hospitalization and $4 \%$ severe illness.$^{[5]}$ In Turkey, as of March 26, the number of patients has been exponentially growing and, currently, it exceeds 2,433 with 59 fatalities. The first case was reported on March 11, 2020 by the Turkish Ministry of Health and first death due to COVID-19 on March 16, 2020.

Clinical characteristics of coronavirus disease 2019 in China showed that the median age was 47 years and $41.9 \%$ of the patients were females. ${ }^{[8]}$ The presentation of COVID-19 was typical with symptoms of fever, dry cough, fatigue, and shortness of breath. ${ }^{[9]}$ However, it can be also clinically asymptomatic. The virus may cause severe respiratory failure by the massive alveolar damage involving the lower respiratory tract or severe acute respiratory distress syndrome (ARDS). COVID-19 can be fatal, particularly in elderly patients and those with comorbidities. Postmortem biopsies showed bilateral diffuse alveolar damage with cellular fibromyxoid exudates, interstitial mononuclear inflammatory infiltrates, dominated by lymphocytes, desquamation of pneumocytes, and hyaline membrane formation. ${ }^{[10]}$ The pathological features of COVID-19 much resemble those seen in SARS and Middle East respiratory syndrome (MERS) coronavirus infection.

According to Chinese experience, older age was associated with a higher risk of development of ARDS and death likely due to impaired immune responses. ${ }^{[11]}$ Another multi-center study showed that older age (odds ratio 1.10, 95\% CI: 1.03-1.17, annual increase; $\mathrm{p}=0.0043)$, higher Sequential Organ Failure Assessment (SOFA) scores (5.65, 2.61-12.23; $\mathrm{p}<0.0001$ ), and D-dimer higher than $1 \mathrm{mug} / \mathrm{L}(18.42,2.64-128.55$; $\mathrm{p}=0.0033$ ) on admission were associated with a poor prognosis. $^{[12]}$

The rate of ARDS ranges from 15 to $30 \%$ among patients who require hospitalization. ${ }^{[13]}$ In case of severe ARDS, adequate tissue oxygenation cannot be optimized, despite maximal mechanical ventilatory support and other treatment strategies. In addition, COVID-19 can cause myocardial injury in approximately $7 \%$ of patients leading to myocardial dysfunction. ${ }^{[14]}$ Cardiovascular comorbidities pose an independent risk for mortality. ${ }^{[12]}$
In the most recent study, Shi et al. ${ }^{[15]}$ demonstrated that cardiac injury, as a common complication $(19.7 \%)$, was associated with significant mortality rates. The authors showed that patients with cardiac injury presented with more severe acute illness as manifested by abnormal laboratory results such as higher levels of $\mathrm{C}$-reactive protein, $\mathrm{N}$-terminal pro-B-type natriuretic peptide (NT-proBNP), and creatinine levels accompanied by more aggressive computed tomography (CT) findings such as multiple mottling and ground-glass opacities. These patients had severe ARDS, and a higher proportion of them required non-invasive or invasive ventilation. ${ }^{[15]}$ Similarly, of these patients with documented cardiac injury, $58 \%$ and $60 \%$ had a history of hypertension, while $25 \%$ and $30 \%$ had a previous cardiac disease in Wang and Shi's reports, respectively. ${ }^{[15,16]}$ Both in cases of respiratory and circulatory failure, refractory to the treatments, extracorporeal life support (ECLS) may be needed.

\section{COVID-19 and ARDS}

Following the incubation period of 2 to 14 days, symptoms may occur, patients are admitted to hospital in approximately 7 days (range, 4 to 8 days), develop shortness of breath, appears in approximately 8 days (range, 5 to 13 days), and need mechanical ventilation support within 10.5 days (range, 7 to 14 days). ${ }^{[17]}$ Expert anesthesiologists from China have recently reported recommendations for tracheal intubation in critically ill patients with COVID-19. ${ }^{[18]}$

Chest imaging findings in patients with COVID-19 are of utmost importance for an objective evaluation of the lung lesions. ${ }^{[19-21]}$ Thin-section CT is not specific for the final diagnosis, but sensitive for the detection, despite negative real time-polymerase chain reaction (RT-PCR) results. Ground glass opacities, consolidation, reticular pattern, and crazy paving pattern are typical CT manifestations of COVID-19. ${ }^{[22,23]}$ In the presence of bilateral, peripheral, posterior or lower zone infiltration, COVID-19 should be suspected. ${ }^{[23,24]}$ The most significant feature of pneumonia caused by SARS-CoV-2 is rapid progression to ARDS, which is seen in $32 \%$ of cases. ${ }^{[25]}$

In general, ARDS can be classified as mild, if the partial pressure of oxygen in arterial blood $\left(\mathrm{PaO}_{2}\right) /$ fraction of inspired oxygen $\left(\mathrm{FiO}_{2}\right)$ value is between 200 and $300 \mathrm{mmHg}$; moderate, if the $\mathrm{PaO}_{2} / \mathrm{FiO}_{2}$ value is between 100 and $200 \mathrm{mmHg}$; and severe, if the $\mathrm{PaO}_{2} / \mathrm{FiO}_{2}$ value is below $100 \mathrm{mmHg}$, while the positive end-expiratory pressure (PEEP) is below 
$5 \mathrm{cmH}_{2} \mathrm{O}$. Patients who develop ARDS should be treated according to treatment protocols launched by national and international organizations including high flow oxygen therapy, non-invasive mechanical ventilation for eligible patients, mechanical ventilation, and prone position, if needed.

\section{COVID-19 and MYOCARDIAL INJURY}

The most challenging clinical scenarios of COVID-19 are respiratory failure, secondary bacterial infections, septic shock, and multiorgan failure induced by ARDS. In addition, myocardial injury and associated complications, such as low cardiac output and arrhythmia, may present with COVID-19. ${ }^{[16]}$ Although cardiac enzymes can be affected during different types of respiratory diseases, myocardial injury due to COVID-19 is caused by several other factors. This condition, called non-coronary (Type II) myocardial infarction, is associated with hypoxia, excessive inflammatory response, and direct damage of the SARS-CoV-2 toward cardiomyocytes. ${ }^{[26]}$

The use of right heart catheterization to differentiate whether a pulmonary disease causes the right heart failure is taken out from the Berlin Criteria for the patients with ARDS. In these patients, troponin and BNP levels and echocardiographic evaluation can help to make the differential diagnosis. While discussing the indication of extracorporeal membrane oxygenation (ECMO), differentiating whether the cardiogenic shock is developed or not, plays an essential role in the decision of which type of ECMO should be applied: veno-arterial (VA) or veno-venous (VV) and appropriate site of cannulation. However, the prognosis cannot be improved in patients with severe ARDS due to COVID-19, even with the support of ECMO. In addition to this, there is no case reported for the use of ECMO for fulminant myocarditis caused by COVID-19 in the literature. Therefore, there is no consensus and sufficient evidence for the indication, implantation, and weaning of ECMO in these patients.

\section{COVID-19 and CARDIOVASCULAR DISEASES}

COVID-19 pandemic puts a great responsibility on cardiologists and cardiovascular surgeons on differentiating elective, urgent, and emergency cases to be performed. In certain countries as in Turkey, intensive care unit beds are still available, but may not be available in the coming days. The ethical dilemma is expected to be solved soon with international collaboration.

\section{WORLDWIDE OUTCOMES OF ECMO SUPPORT in COVID-19 PANDEMIC}

Although the number of cases is exponentially increasing all over the world day by day, the number of patients undergoing ECMO is quite limited. ${ }^{[12,16,27-29]}$ The most important reason for this may be that they have not been published yet. The results obtained from the series published in a short time are shown in Table 1.

\section{RISK ASSESSMENT FOR MORTALITY in COVID-19 PANDEMIC}

COVID-19 infection can create severe clinical pictures with pneumonia, ARDS, shock, and multiorgan failure. In particular, due to the limited number of ECMO devices and excessive workload of the healthcare professionals, it is vital to select the right patients who will benefit maximum. Therefore, it is necessary to know the risk factors for mortality in COVID-19. According to the available evidence within a relatively short period, the most critical risk factors for mortality are:

a. Patient characteristics and comorbidities at the time of hospital admission ${ }^{[12,16,30]}$ advanced age, hypertension, coronary artery disease [CAD],

Table 1. The data and outcomes of ECMO support for COVID-19 patients up to date

\begin{tabular}{|c|c|c|c|c|c|c|c|c|c|}
\hline & \multirow{2}{*}{$\begin{array}{c}\text { Patients } \\
\text { Hospitalized } \\
n\end{array}$} & \multicolumn{2}{|c|}{$\begin{array}{c}\text { Patients requiring } \\
\text { ICU }\end{array}$} & \multirow{2}{*}{$\begin{array}{l}\text { Patients requiring } \\
\text { ECMO } \\
\mathrm{n}\end{array}$} & \multirow{2}{*}{$\frac{\text { Wean }}{\mathrm{n}}$} & \multirow{2}{*}{$\frac{\text { On ECMO }}{\mathrm{n}}$} & \multirow{2}{*}{$\begin{array}{c}\begin{array}{c}\text { Successful weaning } \\
\text { from ECMO }\end{array} \\
\mathrm{n}\end{array}$} & \multicolumn{2}{|c|}{ Mortality } \\
\hline & & $\mathrm{n}$ & $\%$ & & & & & $\mathrm{n}$ & $\%$ \\
\hline Wang et al., 2020 $0^{[16]}$ & 138 & 36 & 26 & 4 & NA & NA & NA & \multicolumn{2}{|c|}{ NA } \\
\hline Huang et al., 2020 27$]$ & 41 & 13 & 32 & 2 & NA & NA & NA & \multicolumn{2}{|c|}{ NA } \\
\hline Chen et al., $2020^{[28]}$ & 99 & 23 & 23 & 3 & NA & NA & NA & 1 & 33 \\
\hline Yang et al., 2020 [29] & 710 & 52 & 7 & 6 & None & 1 & None & 5 & 83 \\
\hline Zhou et al., $2020^{[12]}$ & 191 & 50 & 26 & 3 & None & None & None & 3 & 100 \\
\hline
\end{tabular}

ECMO: Extracorporeal membrane oxygenation; ICU: Intensive care unit; NA: Not applicable 
diabetes mellitus [DM], chronic obstructive pulmonary disease [COPD], chronic renal failure, history of malignancy, high SOFA scores

b. Laboratory findings obtained at the time of hospital admission ${ }^{[12,16,27]}$ leukocytosis, lymphopenia, anemia, thrombocytopenia, high alanine aminotransferase, high lactate dehydrogenase, high creatine kinase, high troponin, high D-dimer, prolonged prothrombin time, high ferritin, high IL-6, high procalcitonin.

\section{ECMO EXPERIENCE DURING PREVIOUS PANDEMICS}

In 2009, during a Swine Flu pandemic, the Extracorporeal Life Support Organization (ELSO) data from Australia and New Zealand were published. Sixty-eight patients received ECMO support for ARDS. The median duration of support was 10 (range, 7 to 15) days, and the ICU and hospital discharge rate was $71 \%$ and $47 \%$ at the time of publication. ${ }^{[31]}$

During the MERS outbreak originating from another type of coronavirus in 2014, a comparative analysis of 17 patients who received ECMO support and 18 patients in the conventional treatment group showed a lower mortality rate in the ECMO group (65\% vs. $100 \%$, respectively). ${ }^{[32]}$

\section{CONSIDERATION OF ECMO SUPPORT IN COVID-19}

In case of persistent hypoxia and hypercarbia despite all the treatment strategies recommended by the national and international guidelines for the adult patient with COVID-19, ECMO support can be considered in patients who meet the following pulmonary criteria:

Patients with respiratory insufficiency who are under mechanical ventilatory support for less than 7 days and
a. PEEP $>12-16 \mathrm{~cm} \mathrm{H}_{2} \mathrm{O}$
b. The tidal volume of $4-6 \mathrm{~mL} / \mathrm{kg}$
c. Plateau pressure $>30 \mathrm{cmH}_{2} \mathrm{O}$
d. $\mathrm{FiO}_{2}>80 \%$
e. $\mathrm{PaO}_{2} / \mathrm{FiO}_{2}$ between $100-150 \mathrm{mmHg}$
f. $\mathrm{PaCO}_{2}>60 \mathrm{mmHg}$ (for more than $6 \mathrm{~h}$ )
g. Blood $\mathrm{pH}<7.25$ (arterial blood gas analysis)
h. Respiratory rate $>35$ breaths per min (for $7 \mathrm{~min}$ )
i. Refractory to prone positioning

In case of persistent cardiogenic shock, refractory to all positive inotropic and vasopressor agents and intra-aortic balloon pump, ECMO therapy can be considered in patients who meet the following cardiac criteria:

a. Left ventricle ejection fraction below $\% 30$ without a history of cardiac disease

b. Progressive deterioration of systolic function; or right heart failure/low cardiac output with accompanying high pulmonary artery pressure.

\section{RECOMMENDATIONS (Figure 1)}

\section{INDICATIONS FOR ECMO SUPPORT}

1. Patients with COVID-19 without any comorbidity

2. Rapidly progressive pneumonia

3. Severe ARDS

4. Diffuse lung injury by SARS-CoV-2 as confirmed by CT scan

5. Patients under the age of 65 years

6. High probability for recovery of pulmonary functions

\section{CONTRAINDICATIONS FOR ECMO SUPPORT}

1. Elderly patients

2. Any age with severe comorbidities (CAD, COPD, DM with end-organ damage, chronic renal failure, end-stage liver failure, known systemic disease, permanent neurological damage, malignancy)

3. Bacterial superinfection

4. Sepsis

5. Disseminated intravascular coagulation

6. Septic shock

Patients who are suitable for these criteria should be considered for ECMO by the Team consisting of the experts from Cardiovascular Surgery, Anesthesiology and Intensive Care, Infectious Diseases, Cardiology, and Respiratory Medicine.

\section{RECOMMENDATIONS FOR ECMO APPLICATIONS}

1. VV-ECMO with routine VV cannulation should be considered in the first place, when ECMO decision is made due to ARDS with aforementioned clinical respiratory status, 


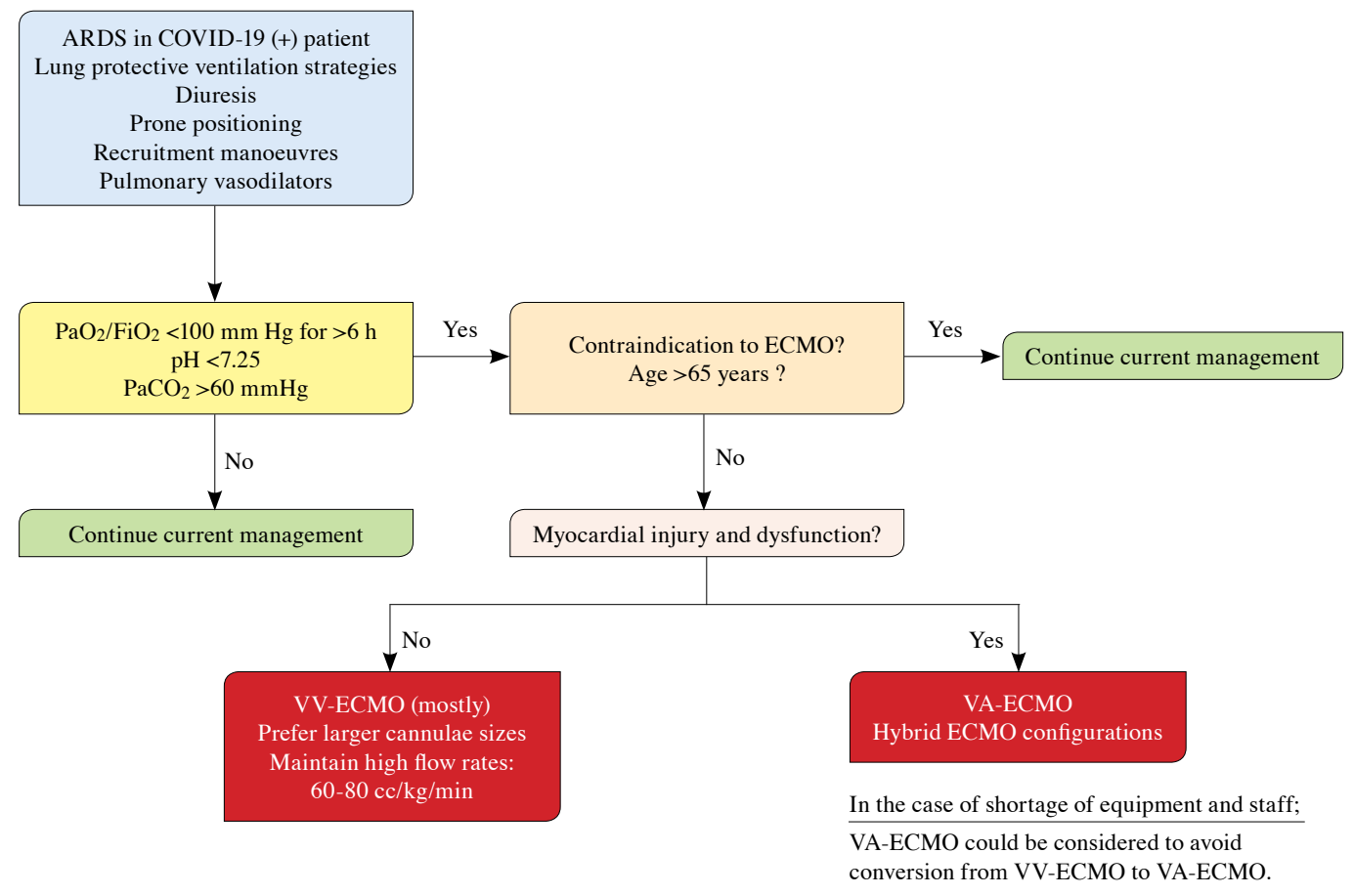

Figure 1. Recommended algorithm for the management of ECMO use in COVID-19.

ARDS: Acute respiratory distress syndrome; ECMO: Extracorporeal membrane oxygenation; VV: Veno-venous; VA: Veno-arterial.

2. In patients with myocardial dysfunction by echocardiographic evaluation, VA-ECMO should be considered.

3. In patients without myocardial dysfunction, VA-ECMO can be considered in the following situations:

a) Patients older than 45 years without any known cardiac or systemic comorbidities, but the history of smoking or antihypertensive medication or other risk factors for CAD, that may be prone to myocardial dysfunction during support

b) New myocardial dysfunction during VV-ECMO

c) In selected cases, to decrease the need for conversion from VV-ECMO to VA-ECMO, if the shortage of equipment and staff is concerned

4. The axillary/subclavian route is suggested for the VA-ECMO to prevent cerebral and coronary hypoxia. For venous cannulation, jugular and femoral routes are optional. If oxygenation is insufficient during the VA-ECMO run, connecting an additional venous inflow for Veno-Arterial-Venous (VAV)-ECMO can be considered.

5. Femoral cannulation should be avoided. If performed thoroughly, a jugular venous cannula should be routinely used to run as VAV-ECMO. The use of an intra-aortic balloon pump (IABP) can be considered in case of insufficient hemodynamic recovery.

6. If the arterial cannula is placed into the femoral artery, distal perfusion cannula should be placed.

7. Oxygenation should always be followed by the $\mathrm{PaO}_{2}$ levels from the arterial blood gas obtained from the right radial artery.

8. Cardiac functions should be monitored regularly during VV-ECMO.

9. Additional procedure (i.e., venting cannula or IABP) for left ventricular unloading should be considered in case VA-ECMO.

10. All the health careers should be supplied with maximal personal protection equipment during the procedure. 
11. The number of health careers during the procedure should be kept minimal.

12. Anticoagulant therapy should be applied regularly, unless bleeding or coagulopathy occurs.

13. Functions of the ECMO device and the data of hemodynamics should be recorded daily by the perfusionists.

14. Despite all the difficulties in a pandemic workload, ECMO decision should be still made by the ECMO Team, and its application should be kept very limited due to unpromising results.

In conclusion, the global outbreak of COVID-19 has again reminded us of the Hippocratic Oath and Principles. Early written recommendations during this pandemic may help healthcare professionals who are under high physical, emotional, and spiritual stress. The indications and contraindications for the levels of cardiopulmonary support in patients with COVID-19 require close international collaboration and sharing the outcomes in transparency.

\section{Acknowledgment}

We would like to thank all the healthcare professionals globally who are risking their lives for their patients.

\section{Declaration of conflicting interests}

The authors declared no conflicts of interest with respect to the authorship and/or publication of this article.

\section{Funding}

The authors received no financial support for the research and/or authorship of this article.

\section{REFERENCES}

1. Dong E, Du H, Gardner L. An interactive web-based dashboard to track COVID-19 in real time. Lancet Infect Dis 2020. pii: S1473-3099(20)30120-1.

2. Wang H, Wang Z, Dong Y, Chang R, Xu C, Yu X, et al. Phase-adjusted estimation of the number of Coronavirus Disease 2019 cases in Wuhan, China. Cell Discov 2020;6:10.

3. Li Q, Guan X, Wu P, Wang X, Zhou L, Tong Y, et al. Early Transmission Dynamics in Wuhan, China, of Novel Coronavirus-Infected Pneumonia. N Engl J Med 2020;382:1199-207.

4. Zou L, Ruan F, Huang M, Liang L, Huang H, Hong Z, et al. SARS-CoV-2 Viral Load in Upper Respiratory Specimens of Infected Patients. N Engl J Med 2020;382:1177-9.

5. Corona Virus Disease 2019 (COVID-19) Pandemic: Increased transmission in the EU/EEA and the UKSeventh Update, March 25, 2020. Available at https:// www.ecdc.europa.eu/sites/default/files/documents/ RRA-seventh-update-Outbreak-of coronavirus-disease-
COVID-19.pdf.

6. Wu F, Zhao S, Yu B, Chen YM, Wang W, Song ZG, et al. A new coronavirus associated with human respiratory disease in China. Nature 2020;579:265-9.

7. Singhal T. A Review of Coronavirus Disease-2019 (COVID19). Indian J Pediatr 2020;87:281-6.

8. Guan WJ, Ni ZY, Hu Y, Liang WH, Ou CQ, He JX, et al. Clinical Characteristics of Coronavirus Disease 2019 in China. N Engl J Med 2020. [Epub ahead of print]

9. Yang W, Cao Q, Qin L, Wang X, Cheng Z, Pan A, et al. Clinical characteristics and imaging manifestations of the 2019 novel coronavirus disease (COVID-19):A multicenter study in Wenzhou city, Zhejiang, China. J Infect 2020;80:388-93.

10. Xu Z, Shi L, Wang Y, Zhang J, Huang L, Zhang C, et al. Pathological findings of COVID-19 associated with acute respiratory distress syndrome. Lancet Respir Med 2020. pii: S2213-2600(20)30076-X.

11. Wu C, Chen X, Cai Y, Xia J, Zhou X, Xu S, et al. Risk Factors Associated With Acute Respiratory Distress Syndrome and Death in Patients With Coronavirus Disease 2019 Pneumonia in Wuhan, China. JAMA Intern Med 2020. [Epub ahead of print]

12. Zhou F, Yu T, Du R, Fan G, Liu Y, Liu Z, et al. Clinical course and risk factors for mortality of adult inpatients with COVID-19 in Wuhan, China: a retrospective cohort study. Lancet 2020. pii: S0140-6736(20)30566-3.

13. MacLaren G, Fisher D, Brodie D. Preparing for the Most Critically Ill Patients With COVID-19: The Potential Role of Extracorporeal Membrane Oxygenation. JAMA 2020. [Epub ahead of print]

14. Clerkin KJ, Fried JA, Raikhelkar J, Sayer G, Griffin JM, Masoumi A, et al. Coronavirus Disease 2019 (COVID-19) and Cardiovascular Disease. Circulation 2020. [Epub ahead of print]

15. Shi S, Qin M, Shen B, Cai Y, Liu T, Yang F, et al. Association of Cardiac Injury With Mortality in Hospitalized Patients With COVID-19 in Wuhan, China. JAMA Cardiol 2020. [Epub ahead of print]

16. Wang D, Hu B, Hu C, Zhu F, Liu X, Zhang J, et al. Clinical Characteristics of 138 Hospitalized Patients With 2019 Novel Coronavirus-Infected Pneumonia in Wuhan, China. JAMA 2020. [Epub ahead of print]

17. Ronco C, Navalesi P, Vincent JL. Coronavirus epidemic: preparing for extracorporeal organ support in intensive care. Lancet Respir Med 2020;8:240-1.

18. Zuo MZ, Huang YG, Ma WH, Xue ZG, Zhang JQ, Gong YH, et al. Expert Recommendations for Tracheal Intubation in Critically ill Patients with Noval Coronavirus Disease 2019. Chin Med Sci J 2020. [Epub ahead of print]

19. Guan CS, Lv ZB, Yan S, Du YN, Chen H, Wei LG, et al. Imaging Features of Coronavirus disease 2019 (COVID19): Evaluation on Thin-Section CT. Acad Radiol 2020. pii: S1076-6332(20)30143-4. [Epub ahead of print]

20. Li M, Lei P, Zeng B, Li Z, Yu P, Fan B, et al. Coronavirus Disease (COVID-19): Spectrum of CT Findings and Temporal Progression of the Disease. Acad Radiol 2020. pii: S1076-6332(20)30144-6. [Epub ahead of print] 
21. Zu ZY, Jiang MD, Xu PP, Chen W, Ni QQ, Lu GM, et al. Coronavirus Disease 2019 (COVID-19): A Perspective from China. Radiology 2020:200490. [Epub ahead of print]

22. Ye Z, Zhang Y, Wang Y, Huang Z, Song B. Chest CT manifestations of new coronavirus disease 2019 (COVID-19): a pictorial review. Eur Radiol 2020. [Epub ahead of print]

23. Yoon SH, Lee KH, Kim JY, Lee YK, Ko H, Kim KH, et al. Chest Radiographic and CT Findings of the 2019 Novel Coronavirus Disease (COVID-19): Analysis of Nine Patients Treated in Korea. Korean J Radiol 2020;21:494-500.

24. Zhao W, Zhong Z, Xie X, Yu Q, Liu J. Relation Between Chest CT Findings and Clinical Conditions of Coronavirus Disease (COVID-19) Pneumonia: A Multicenter Study. AJR Am J Roentgenol 2020:1-6. [Epub ahead of print]

25. Rodriguez-Morales AJ, Cardona-Ospina JA, GutiérrezOcampo E, Villamizar-Peña R, Holguin-Rivera Y, EscaleraAntezana JP, et al. Clinical, laboratory and imaging features of COVID-19: A systematic review and meta-analysis. Travel Med Infect Dis 2020:101623.

26. Troponin and BNP Use in COVID-19. Available at: https:// www.acc.org/latest-in cardiology/articles/2020/03/18/15/25/ troponin-and-bnp-use-in-covid19.

27. Huang C, Wang Y, Li X, Ren L, Zhao J, Hu Y, et al. Clinical features of patients infected with 2019 novel coronavirus in Wuhan, China. Lancet 2020;395:497-506.

28. Chen N, Zhou M, Dong X, Qu J, Gong F, Han Y, et al. Epidemiological and clinical characteristics of 99 cases of 2019 novel coronavirus pneumonia in Wuhan, China: a descriptive study. Lancet 2020;395:507-13.

29. Yang X, Yu Y, Xu J, Shu H, Xia J, Liu H, et al. Clinical course and outcomes of critically ill patients with SARSCoV-2 pneumonia in Wuhan, China: a single-centered, retrospective, observational study. Lancet Respir Med 2020. pii: S2213-2600(20)30079-5. [Epub ahead of print]

30. Liang W, Guan W, Chen R, Wang W, Li J, Xu K, et al. Cancer patients in SARS-CoV-2 infection: a nationwide analysis in China. Lancet Oncol 2020;21:335-7.

31. Australia and New Zealand Extracorporeal Membrane Oxygenation (ANZ ECMO) Influenza Investigators, Davies A, Jones D, Bailey M, Beca J, Bellomo R, et al. Extracorporeal Membrane Oxygenation for 2009 Influenza A(H1N1) Acute Respiratory Distress Syndrome. JAMA 2009;302:1888-95.

32. Alshahrani MS, Sindi A, Alshamsi F, Al-Omari A, El Tahan M, Alahmadi B, et al. Extracorporeal membrane oxygenation for severe Middle East respiratory syndrome coronavirus. Ann Intensive Care 2018;8:3 